\title{
Preliminary approach to detect amylolytic and pectinolytic activities from maca (Lepidium meyenii Walp.)
}

\author{
Gerby Giovanna Rondan-Sanabria, Tatiana da Costa Raposo Pires, Flavio Finardi Filho* \\ Departamento de Alimentos e Nutrição Experimental, Faculdade de Ciências Farmacêuticas, Universidade \\ de São Paulo
}

*Correspondence:

F. Finardi Filho

Departamento de Alimentos e

Nutrição Experimental

Faculdade de Ciências Farmacêuticas

Universidade de São Paulo

Av. Prof. Lineu Prestes, Bloco 14

05508-900 - São Paulo, SP - Brasil

E-mail: ffinardi@usp.br

\begin{abstract}
Amylase (AM), pectinesterase (PE) and polygalacturonase (PG) were extracted from maca roots (Lepidium meyenii Walp). The response surface model was used to determine the optimum conditions of $\mathrm{pH}$ and temperature activity of each enzyme on the crude extract. The highest values of AM activity occurred at $\mathrm{pH}$ 6.1 and $33.6^{\circ} \mathrm{C}$, very close to the experimental central point. The $P E$ activity had a maximum activity at pH 6.6 and 49.4 and $P G$ activity showed optimum activity at pH 5.4 and $46{ }^{\circ} \mathrm{C}$.
\end{abstract}

\author{
Uniterms \\ - Maca \\ - Lepidium meyenii Walp \\ - Amylase \\ - Pectinesterase \\ - Polygalacturonase \\ - Response surface model
}

\section{INTRODUCTION}

Maca (Lepidium meyenii Walp.) is a tuber that has one of the highest frost tolerances among other native cultivated plants growing exclusively at high altitudes $(3,700-4,500 \mathrm{~m})$ at the Peruvian Andes. No other crop plant, except bitter potatoes and Alpine grasses, gives reliable yields at 4,400 $\mathrm{m}$ (Toledo et al., 1998). As an ethnical food, the root is the edible part of maca used for human consumption due to its nutritional value, as well as to its exotic characteristic of taste and flavor. It became popular as a botanical extract due to, among other things, claimed energy and fertility function (Tellez et al., 2002). The tuber is rich in carbohydrates $(59.0 \%)$, proteins $(10.2 \%)$, fibers $(8.5 \%)$ and lipids (2.2\%), as well as a large amount of amino acids and higher levels of iron and calcium than potatoes (Tellez et al., 2002; Quirós, Cárdenas, 2004). The tuber of this plant has been well appreciated since the pre-Incan times. During the Inca Empire, maca consumption was allowed to the nobility, the clergy, and the privileged classes; it was used as a gift prize to warriors. Nowadays, Andean people consume maca tuber boiled or roasted, as a spice to prepare dishes, soups and also drinks (Piacente et al., 2002).

Although maca composition and compounds have been studied (Tellez et al., 2002; Piacente et al., 2002; Dini, Tenore, Dini, 2002; Sandoval et al., 2002; Comas et al., 1997), the biochemical activities of their enzymes were not reported yet. In contrast with other roots and tubers like cassava (Campos, de Carvalho, 1990; Matos da Veiga, 2002; Hirose, 1986), potato (Cho, Ahn, 1999; Kahn et al., 1981), yam (Oluoha, Ugochukwu, 1995), Peruvian carrot (Pires, Finardi-Filho, 2005; Pires, Veiga, Finardi-Filho, 2002) and sweet-potato (Hagenimana, Vézina, Simard, 1994), far less data are available about the biochemical characteristics of its enzyme activity. During storage, maca roots present loss of humidity and texture, which would be related to the action of endogenous carbohydrases. In addition, a high degree of amylolytic activity was found in preliminary studies, with high value of enzyme activity (around $170 \mathrm{U}_{\mathrm{AM}}$ ) detected at $\mathrm{pH} 6.1$ and $4{ }^{\circ} \mathrm{C}$ (unpublished results). The action of pectinolytic and amylolytic enzymes might be connected to the deterioration process of the tuber after harvest. 
In this study the response surface methodology (RSM) was applied to determine the optimum $\mathrm{pH}$ and temperature of amylase, pectinesterase and polygalacturonase activities of maca roots.

\section{MATERIAL AND METHODS}

\section{Roots}

Roots of maca (Lepidium meyenii Walp.) harvested during the year 2003 and stored at $-18{ }^{\circ} \mathrm{C}$ were used in the present work for enzyme extraction. The roots were purchased at the local market in Peru.

\section{Chemicals}

Citric pectin, sodium phosphate, potato starch, alcohol oxidase from $P$. pastoris (EC 1.1.3.13), 2,4pentanedione, galacturonic acid, polygalacturonic acid, sodium acetate and bovine serum albumin (BSA) were purchased from Sigma Chemical Co., St. Louis. 2Cyanoacetamide was obtained from Aldrich Chemical Co., Steinhein. All other reagents were analytical grade.

\section{Amylase extraction and assay}

For AM extraction, a method previously described was used (Pires, Veiga, Finardi-Filho, 2002). After washing, the roots were peeled off and diced. A sample of $25 \mathrm{~g}$ was homogenized with $100 \mathrm{~mL}$ of $0.2 \mathrm{M}$ phosphate buffer ( $\mathrm{pH}$ 6.0) in a regular blender. The crude extract was centrifuged at $10,300 \times \mathrm{g}$ for $30 \mathrm{~min}$ at $4{ }^{\circ} \mathrm{C}$. The supernatant was dialyzed against distilled water at $4{ }^{\circ} \mathrm{C}$ for $24 \mathrm{~h}$. The sample was stored at $-18^{\circ} \mathrm{C}$ until its utilization.

The total amylolytic activity was determined according to Street (1974) by measuring starch-iodine complex. Volumes of $100 \mu \mathrm{L}$ of enzymatic extract and $0.1 \mathrm{M} \mathrm{NaCl}$ solution (1:1) were incubated with $200 \mu \mathrm{L}$ of potato starch $0.1 \%$ solution, $500 \mu \mathrm{L}$ of $0.1 \mathrm{M}$ acetate or phosphate buffer at $\mathrm{pH}$ ranging from 5.8 to 7.2 (Table I) and $200 \mu \mathrm{L}$ of $\mathrm{HCl} 0.01 \mathrm{M}$ solution, for 15 minutes, at different temperatures from 18 to $46{ }^{\circ} \mathrm{C}$ (Table I). The reaction was interrupted by the addition of $400 \mu \mathrm{L}$ of iodine solution. The volume was completed to $10 \mathrm{~mL}$ with distilled water and the absorbance was read at $578 \mathrm{~nm}$. One amylolytic activity unity $\left(1 \mathrm{U}_{\mathrm{AM}}\right)$ was calculated by the amount of starch (ng) hydrolyzed per minute per milligram of protein.

TABLE I - Experimental conditions of maca enzyme activity in coded and real values ${ }^{\mathrm{a}}$

\begin{tabular}{|c|c|c|c|c|c|c|c|c|}
\hline \multirow[t]{2}{*}{ Experimen } & \multicolumn{2}{|c|}{ Coded values } & \multicolumn{6}{|c|}{ Real values } \\
\hline & & & \multicolumn{2}{|c|}{$\mathbf{A M}$} & \multicolumn{2}{|c|}{ PG } & \multicolumn{2}{|c|}{$\mathbf{P E}$} \\
\hline Treatment & $\mathrm{x}_{1}$ & $\mathrm{x}_{2}$ & $\mathrm{pH}$ & $\mathrm{T}\left({ }^{\circ} \mathrm{C}\right)$ & $\mathrm{pH}$ & $\mathrm{T}\left({ }^{\circ} \mathrm{C}\right)$ & $\mathrm{pH}$ & $\mathrm{T}\left({ }^{\circ} \mathrm{C}\right)$ \\
\hline 1 & -1 & -1 & 6.0 & 22 & 4.5 & 25 & 5.5 & 45 \\
\hline 2 & -1 & 1 & 6.0 & 42 & 4.5 & 45 & 5.5 & 55 \\
\hline 3 & 1 & -1 & 7.0 & 22 & 5.5 & 25 & 7.5 & 45 \\
\hline 4 & 1 & 1 & 7.0 & 42 & 5.5 & 45 & 7.5 & 55 \\
\hline 5 & 0 & 0 & 6.5 & 32 & 5.0 & 35 & 6.5 & 50 \\
\hline 6 & 0 & 0 & 6.5 & 32 & 5.0 & 35 & 6.5 & 50 \\
\hline 7 & 0 & 0 & 6.5 & 32 & 5.0 & 35 & 6.5 & 50 \\
\hline 8 & 1.4142 & 0 & 7.2 & 32 & 5.7 & 35 & 7.9 & 50 \\
\hline 9 & -1.4142 & 0 & 5.8 & 32 & 4.3 & 35 & 5.1 & 50 \\
\hline 10 & 0 & 1.4142 & 6.5 & 46 & 5.0 & 49 & 6.5 & 57 \\
\hline 11 & 0 & -1.4142 & 6.5 & 18 & 5.0 & 21 & 6.5 & 43 \\
\hline 12 & 0 & 0 & 6.5 & 32 & 5.0 & 35 & 6.5 & 50 \\
\hline 13 & 0 & 0 & 6.5 & 32 & 5.0 & 35 & 6.5 & 50 \\
\hline 14 & 0 & 0 & 6.5 & 32 & 5.0 & 35 & 6.5 & 50 \\
\hline
\end{tabular}

${ }^{\mathrm{a}}$ For the AM activity, $\mathrm{x}_{1}=(\mathrm{pH}-6.5) / 0.5$, where $\mathrm{pH}$ ranged from 5.8 to 7.2 and $\mathrm{x}_{2}=(\mathrm{T}-32) / 10$, where $\mathrm{T}$ ranged from 18 to $46{ }^{\circ} \mathrm{C}$; For the $\mathrm{PG}$ activity, $\mathrm{x}_{1}=(\mathrm{pH}-5.0) / 0.5$, where $\mathrm{pH}$ ranged from 4.3 to $5.7, \mathrm{x}_{2}=(\mathrm{T}-35) / 10$, where $\mathrm{T}$ ranged from 21 to $49^{\circ} \mathrm{C}$; for the $\mathrm{PE}$ activity, $\mathrm{x}_{1}=(\mathrm{pH}-6.5) / 1.0$, where $\mathrm{pH}$ ranged from 5.1 to $7.9, \mathrm{x}_{2}=(\mathrm{T}-50) / 5$, where $\mathrm{T}$ ranged from 43 to $57^{\circ} \mathrm{C}$. 


\section{Pectinesterase and polygalacturonase extraction and assay}

$\mathrm{PE}$ and PG were extracted according to previous work (Pires, Finardi-Filho, 2005). A sample of $50 \mathrm{~g}$ of maca roots was homogenized in $100 \mathrm{~mL}$ of $\mathrm{NaCl} 1.0 \mathrm{M}$ for $2 \mathrm{~min}$, in a regular blender. The homogenate was adjusted to $\mathrm{pH} 8.5$ and 6.0 for PE and PG extraction, respectively, by the addition of $2.0 \mathrm{M} \mathrm{NaOH}$ and $2.0 \mathrm{M}$ acetic acid. The homogenate was stirred for $4 \mathrm{~h}$ at $4^{\circ} \mathrm{C}$ and then centrifuged at $10,300 \mathrm{x} g$ for 30 min at $4{ }^{\circ} \mathrm{C}$. The supernatant, called crude enzymatic extract, was used directly as enzyme source.

The PE activity was determined by methanol production as a consequence of pectin hydrolysis, according to Klavons and Bennet (1986) method: $100 \mu \mathrm{L}$ of enzymatic extract was added to $100 \mu \mathrm{L}$ solution containing either $100 \mathrm{mM}$ sodium phosphate $(0.1 \mathrm{M})$, or acetate buffer $(0.1 \mathrm{M})$, pH ranging from 5.1 to 7.9 (Table I) and $0.1 \%$ of pectin. The reaction mixture was incubated at different temperatures from 43 to $57{ }^{\circ} \mathrm{C}$, for $15 \mathrm{~min}$ (Table I) in microfuge tubes. The reaction was stopped by heating at $100^{\circ} \mathrm{C}$ in a water bath for $3 \mathrm{~min}$ and the mixture, cooled to $25^{\circ} \mathrm{C}$, was diluted to $2.0 \mathrm{~mL}$ with $20 \mathrm{mM}$ Tris$\mathrm{HCl}, \mathrm{pH} 7.5$, and $1 \mathrm{U}$ of alcohol oxidase was added. After $15 \mathrm{~min}$ at $25^{\circ} \mathrm{C}, 1.0 \mathrm{~mL}$ of $20 \mathrm{mM}$ 2-4-pentanodione in 2,0 $\mathrm{M}$ ammonium phosphate was added and the reaction mixture placed in a water bath at $60{ }^{\circ} \mathrm{C}$ for $15 \mathrm{~min}$. The absorbance was measured at $412 \mathrm{~nm}$ against a blank made with the same components but with the enzymatic extract previously boiled for $5 \mathrm{~min}$. A calibration curve, using methanol as a standard, was prepared ranging from 0 to $435 \mathrm{nmoles} / \mathrm{mL}$ of methanol, considering that the correlation between color development and methanol concentration were linear up to that limit. One enzyme activity unit was expressed by $1.0 \mu \mathrm{mol} \mathrm{MeOH}$ x mg protein $^{-1} \mathrm{x}$ min $^{-1}$

The assay of PG activity was based on the hydrolytic release of reducing groups from polygalacturonic acid according to Gross (1982) and Honda et al. (1982) methods. Reaction mixtures containing $10 \mu \mathrm{L}$ of enzymatic extract in $30 \mu \mathrm{L}$ of acetate or phosphate buffer $\mathrm{pH}$ ranged from 4.3 to 5.7 (Table I) and $150 \mu \mathrm{L}$ of the same buffer, with $0.2 \%$ of polygalacturonic acid were incubated for $2 \mathrm{~h}$ at different temperatures from 21 to $40{ }^{\circ} \mathrm{C}$ (Table I). The reaction was stopped by adding $1.8 \mathrm{~mL}$ of $100 \mathrm{mM}$ borate buffer (pH 9.0), followed by $200 \mu \mathrm{L}$ of $1 \% 2$-cyanoacetamide solution. The samples were mixed and immersed in a boiling water bath for $10 \mathrm{~min}$. After equilibration at $25^{\circ} \mathrm{C}$, the amount of reducing sugars was measured at 276 nm against a blank made up with the same components but with inactivated enzyme extract, boiled for $5 \mathrm{~min}$. A calibration curve, using galacturonic acid as a standard, was prepared from 0 to $250 \mu \mathrm{g} / \mathrm{mL}$. One unit of enzymatic activity was expressed by $1.0 \mu \mathrm{g}$ of galacturonic acid produced $\mathrm{x}$ mg of protein ${ }^{-1} \mathrm{x} \mathrm{h}^{-1}$.

\section{Protein quantification}

The protein concentration was measured by the Bradford (1976) method, using bovine serum albumin as standard.

\section{Experimental design: RSM and data analysis}

The response surface model, the main effects and the interaction among the different factors, each at two different levels, can be simultaneously investigated. The central composite face design (CCFD) was used with two variables, at five levels and six replicates at the central point, for a total of 14 experiments (Barros Neto, Scarminio, Bruns, 1996). The two factors studied included $\mathrm{pH}\left(\mathrm{x}_{1}\right)$ and temperature $\left(\mathrm{x}_{2}\right)$ of enzyme activity of maca extracts showing the following experimental conditions of the central point: $\mathrm{pH}=6.5$ and $\mathrm{T}=$ $32{ }^{\circ} \mathrm{C}$ for AM activity; $\mathrm{pH}=5.0$ and $\mathrm{T}=35^{\circ} \mathrm{C}$ for $\mathrm{PG}$ activity and $\mathrm{pH}=6.5$ and $\mathrm{T}=50^{\circ} \mathrm{C}$ for $\mathrm{PE}$ activity of enzyme extract, chosen after preliminary laboratory trails. The experimental index number, scaled values and real values are shown in Table I. The scaled values in which $\mathrm{x}_{1}=(\mathrm{pH}-6.5) / 0.5, \mathrm{pH}$ ranged from 5.8 to $7.2, \mathrm{x}_{2}=(\mathrm{T}-32) / 10$, $\mathrm{T}$ ranged from 18 to $46{ }^{\circ} \mathrm{C}$ for $\mathrm{AM} ; \mathrm{x}_{1}=(\mathrm{pH}-5.0) / 0.5$, where $\mathrm{pH}$ ranged from 4.3 to 5.7 , $\mathrm{x}_{2}=(\mathrm{T}-35) / 10$, $\mathrm{T}$ ranged from 21 to $49^{\circ} \mathrm{C}$ for $\mathrm{PG}$ activity and $\mathrm{x}_{1}=(\mathrm{pH}-6.5) / 1.0, \mathrm{pH}$ ranged from 5.1 to $7.9, \mathrm{x}_{2}=(\mathrm{T}-$ 50)/5, T ranged from 43 to $57{ }^{\circ} \mathrm{C}$ for PE activity. Using the Statistical program, SAS version 6.0 (SAS Institute Inc., Cary, $\mathrm{NC}$ ) for the regression analysis of the experimental data obtained, the following response variables were obtained: $\mathrm{Y}_{1}$ $=\mathrm{AM}$ activity $\left(\mathrm{U}_{\mathrm{AM}}\right)$, and $\mathrm{Y}_{2}=\mathrm{PG}$ activity $\left(\mathrm{U}_{\mathrm{PG}}\right)$ and $\mathrm{Y}_{3}=\mathrm{PE}$ activity $\left(\mathrm{U}_{\mathrm{PE}}\right)$.

The use of central composite design allows the dependent variables to be expressed as a polynomial model of the form:

$\mathrm{y}_{\mathrm{obs}}=\mathrm{b}_{\mathrm{o}}+\mathrm{b}_{1} \mathrm{x}_{1}+\mathrm{b}_{2} \mathrm{x}_{2}+\mathrm{b}_{11} \mathrm{x}_{1} \mathrm{x}_{1}+\mathrm{b}_{22} \mathrm{x}_{2} \mathrm{x}_{2}+\mathrm{b}_{12} \mathrm{x}_{1} \mathrm{x}_{2}+\mathrm{e}$

where

$\mathrm{b}_{0}=$ constant;

$b_{1}$ and $b_{2}=$ main effect of each process variable ( $\mathrm{pH}$ and temperature);

$b_{12}=$ interaction effect between the variables;

$b_{11}$ and $b_{22}=$ effect of square variables;

$\mathrm{y}_{\mathrm{obs}}=$ independent variable (AM, PG or PE activity);

$\mathrm{x}=$ factor $\left(\mathrm{x}_{1}=\mathrm{pH}\right.$ and $\mathrm{x}_{2}=$ Temperature $)$;

$\mathrm{e}=$ residual error $\left(\mathrm{e}=\mathrm{y}_{\mathrm{obs}}-\mathrm{y}_{\text {calc }}\right)$. 


\section{RESULTS}

The experimental results of enzyme activity by a complete two-factor five-level factorial experiment design augment with six central points are shown in Table II. Tables III, IV and V represent the ANOVA of AM, PG and $\mathrm{PE}$ activity as a function of $\mathrm{pH}$ and temperature of enzyme activity of maca extract. The achieved mathematical model, evaluated by the statistical software and expressed in scale variables, was:

$\mathrm{y}_{\text {calc }}\left(\mathrm{U}_{\mathrm{AM}}\right)=244.41-14.30 \mathrm{x}_{1}-0.08 \mathrm{x}_{2}-8.77 \mathrm{x}_{1} \mathrm{x}_{1}-5.69 \mathrm{x}_{2} \mathrm{x}_{2}-3.16 \mathrm{x}_{1} \mathrm{x}_{2}$

$\mathrm{y}_{\text {calc }}\left(\mathrm{U}_{\mathrm{PG}}\right)=160.94+5.10 \mathrm{x}_{1}+4.91 \mathrm{x}_{2}-19.73 \mathrm{x}_{1} \mathrm{x}_{1}-8.95 \mathrm{x}_{2} \mathrm{x}_{2}+20.84 \mathrm{x}_{1} \mathrm{x}_{2}$

$\mathrm{y}_{\text {calc }}\left(\mathrm{U}_{\mathrm{PE}}\right)=35.28+2.26 \mathrm{x}_{1}-1.05 \mathrm{x}_{2}-10.49 \mathrm{x}_{1} \mathrm{x}_{1}-4.36 \mathrm{x}_{2} \mathrm{x}_{2}-0.11 \mathrm{x}_{1} \mathrm{x}_{2}$

The $\mathrm{pH}\left(\mathrm{x}_{1}\right)$, square terms of $\mathrm{pH}\left(\mathrm{x}_{1} \mathrm{x}_{1}\right)$ and temperature $\left(\mathrm{x}_{2} \mathrm{x}_{2}\right)$ of the reaction medium influenced significantly the AM activity from the root extracts $(\mathrm{p}<0.05$, see Table III). The estimation of the model gave $\mathrm{R}_{\mathrm{AM}}{ }^{2}=0.88$ and $\mathrm{R}_{\mathrm{AM} \text { adj }}^{2}=0.81$. Since the coefficients of the above equation are all negative, the response surface suggest to have a maximum point. Figure 1 represents the $\mathrm{RSM}$ for AM activity as a function of $\mathrm{pH}$ and temperature of enzyme activity. The optimal conditions for AM activity occurred at $\mathrm{pH} 6.1$ and $33.6^{\circ} \mathrm{C}$, very close to the central point (see Table II). At this point, the model predicts the

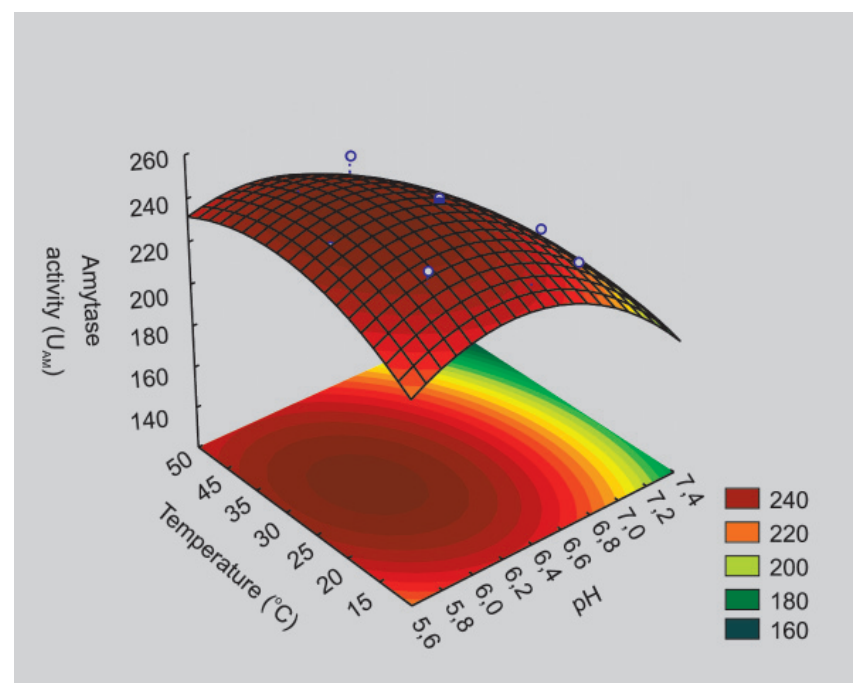

FIGURE 1 - RSM for AM activity $\left(\mathrm{U}_{\mathrm{AM}}\right)$ as a function of $\mathrm{pH}$ and temperature of reaction medium. Experimental conditions at the central point $(0.0)$ were $\mathrm{pH}=6.5$ and temperature $=32^{\circ} \mathrm{C}$. See Tables I and II for details.

highest enzyme activity of $250.38 \mathrm{U}_{\mathrm{AM}}$.

The results of ANOVA for PG activity (Figure 2 and Table II) show that the linear terms $\left(\mathrm{x}_{1}\right.$ and $\left.\mathrm{x}_{2}\right)$ were not significant (see Table IV). The square terms of $\mathrm{pH}\left(\mathrm{x}_{1} \mathrm{x}_{1}\right)$ and temperature $\left(\mathrm{x}_{2} \mathrm{x}_{2}\right)$ as well as the interaction of $\mathrm{pH}$ and temperature $\left(\mathrm{x}_{1} \mathrm{x}_{2}\right)$ of the reaction medium influenced $\mathrm{PG}$ activity significantly from the root extracts $(\mathrm{p}<0.05$, Table

TABLE II - Effect of pH and temperature on AM, PG and PE activity of maca enzyme extracts ${ }^{\mathrm{a}}$

\begin{tabular}{lrrrcc}
\hline Experiment & \multicolumn{3}{c}{ Coded values } & \multicolumn{3}{c}{ Experimental values } \\
\hline Treatment & $\mathrm{X}_{1}$ & $\mathrm{X}_{2}$ & $\mathrm{U}_{\mathrm{AM}}$ & $\mathrm{U}_{\mathrm{PG}}$ & $\mathrm{U}_{\mathrm{PE}}$ \\
\hline 1 & -1 & -1 & 247.68 & 135.10 & 15.75 \\
2 & -1 & 1 & 241.22 & 112.12 & 13.96 \\
3 & 1 & -1 & 221.27 & 116.24 & 20.75 \\
4 & 1 & 1 & 202.19 & 176.60 & 18.54 \\
5 & 0 & 0 & 245.89 & 161.72 & 34.41 \\
6 & 0 & 0 & 246.79 & 160.80 & 34.99 \\
7 & 0 & 0 & 244.71 & 161.83 & 34.66 \\
8 & 1.414 & 0 & 211.44 & 117.01 & 20.50 \\
9 & -1.414 & 0 & 246.05 & 120.45 & 14.48 \\
10 & 0 & 1.414 & 241.65 & 140.97 & 28.18 \\
11 & 0 & -1.414 & 228.15 & 139.58 & 31.31 \\
12 & 0 & 0 & 243.65 & 160.98 & 37.25 \\
13 & 0 & 0 & 242.96 & 159.74 & 35.52 \\
14 & 0 & 0 & 242.45 & 160.57 & 34.87 \\
\hline
\end{tabular}

${ }^{\mathrm{a}}$ For the AM activity, $\mathrm{x}_{1}=(\mathrm{pH}-6.5) / 0.5$, where $\mathrm{pH}$ ranged from 5.8 to 7.2 and $\mathrm{x}_{2}=(\mathrm{T}-32) / 10$, where $\mathrm{T}$ ranged from 18 to $46{ }^{\circ} \mathrm{C}$; For the $\mathrm{PG}$ activity, $\mathrm{x}_{1}=(\mathrm{pH}-5.0) / 0.5$, where $\mathrm{pH}$ ranged from 4.3 to $5.7, \mathrm{x}_{2}=(\mathrm{T}-35) / 10$, where T ranged from 21 to $49^{\circ} \mathrm{C}$; for the $\mathrm{PE}$ activity, $\mathrm{x}_{1}=(\mathrm{pH}-6.5) / 1.0$, where $\mathrm{pH}$ ranged from 5.1 to $7.9, \mathrm{x}_{2}=(\mathrm{T}-50) / 5$, where $\mathrm{T}$ ranged from 43 to $57^{\circ} \mathrm{C}$. 
TABLE III - ANOVA of AM activity as a function of $\mathrm{pH}\left(\mathrm{x}_{1}\right)$ and temperature $\left(\mathrm{x}_{2}\right)$ of enzyme activity of maca extract

\begin{tabular}{lccccc}
\hline Effects & Sum of squares & Degrees of freedom & Medium squares & F-value & p-value \\
\hline $\mathrm{x}_{1}$ & 1635.553 & 1 & 1635.553 & 40.23120 & 0.000222 \\
$\mathrm{x}_{1} \mathrm{x}_{1}$ & 567.291 & 1 & 567.291 & 13.95418 & 0.005742 \\
$\mathrm{x}_{2}$ & 5.203 & 1 & 5.203 & 0.12798 & 0.729795 \\
$\mathrm{x}_{2} \mathrm{x}_{2}$ & 238.832 & 1 & 238.832 & 5.87478 & 0.041603 \\
$\mathrm{x}_{1} \mathrm{x}_{2}$ & 39.816 & 1 & 39.816 & 0.97939 & 0.351333 \\
Error & 325.231 & 8 & 40.654 & - & - \\
Total SS & 2759.853 & 13 & - & - & - \\
\hline
\end{tabular}

TABLE IV - ANOVA of PG activity as a function of $\mathrm{pH}\left(\mathrm{x}_{1}\right)$ and temperature $\left(\mathrm{x}_{2}\right)$ of enzyme activity of maca extract

\begin{tabular}{lccccc}
\hline Effects & Sum of squares & Degrees of freedom & Medium squares & F-value & p-value \\
\hline $\mathrm{x}_{1}$ & 207.661 & 1 & 207.661 & 3.08067 & 0.117304 \\
$\mathrm{x}_{1} \mathrm{x}_{1}$ & 2873.415 & 1 & 2873.415 & 42.62740 & 0.000182 \\
$\mathrm{x}_{2}$ & 193.537 & 1 & 193.537 & 2.87115 & 0.128629 \\
$\mathrm{x}_{2} \mathrm{x}_{2}$ & 591.850 & 1 & 591.850 & 8.78016 & 0.018060 \\
$\mathrm{x}_{1} \mathrm{x}_{2}$ & 1736.389 & 1 & 1736.389 & 25.75950 & 0.000959 \\
Error & 539.262 & 8 & 67.408 & - & - \\
Total SS & 5961.236 & 13 & - & - & - \\
\hline
\end{tabular}

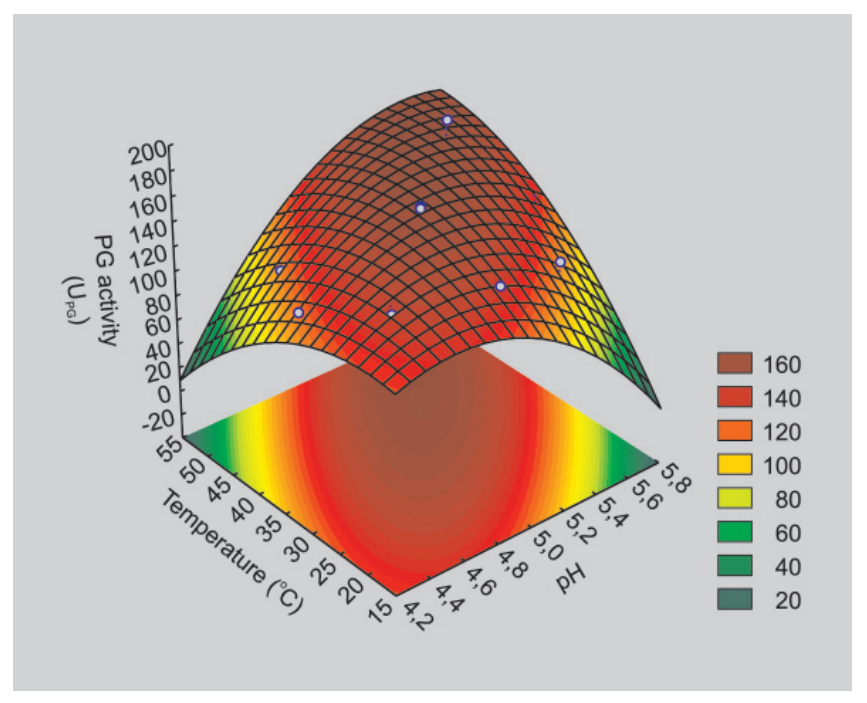

FIGURE 2 - RSM for PG activity $\left(\mathrm{U}_{\mathrm{PG}}\right)$ as a function of $\mathrm{pH}$ and temperature of reaction medium. Experimental conditions at the central point $(0.0)$ were $\mathrm{pH}=5.0$ and temperature $=35^{\circ} \mathrm{C}$. See Tables I and II for details.

IV). The estimation of the model gave $\mathrm{R}_{\mathrm{PG}}{ }^{2}=0.91$ and $\mathrm{R}_{\mathrm{PG} \text { adj }}^{2}=0.85$. The optimum $\mathrm{pH}$ and temperature of $\mathrm{PG}$ activity occurred at $\mathrm{pH} 5.4$ and $46{ }^{\circ} \mathrm{C}$. The maximum response of PG activity, predicted from the model, was 165.46 UPG.

The PE activity (Figure 3 and Table II) is significantly influenced by the square terms of $\mathrm{pH}\left(\mathrm{x}_{1} \mathrm{x}_{1}\right)$ and temperature $\left(\mathrm{x}_{2} \mathrm{x}_{2}\right)$ of the reaction medium of the maca enzyme extracts $(\mathrm{p}<0.05$, see Table $\mathrm{V})$. The evaluation of the model showed $\mathrm{R}_{\mathrm{PE}}{ }^{2}=0.92$ and $\mathrm{R}_{\mathrm{PE} \text { adj }}{ }^{2}=0.87$. The best conditions of $\mathrm{PE}$ activity occurred at $\mathrm{pH} 6.6$ and $49.4{ }^{\circ} \mathrm{C}$, very close to the central point (see Table II). The highest value of PE activity predicted by the RSM model was $35.47 \mathrm{U}_{\mathrm{PE}}$.

\section{DISCUSSION}

The activity of amylolytic and pectinolytic enzymes from maca roots has been studied to understand their deteriorative process. These two groups of enzymes are related to the carbohydrate breakdown and softening during the sprout or the senescence in roots and tubers. Maca presents a high degree of AM activity $\left(170 \mathrm{U}_{\mathrm{AM}}\right)$ comparatively to other crops, like cassava $127 \mathrm{U}_{\mathrm{AM}}$ (Pascoal, 2005) and Peruvian carrot $225 \mathrm{U}_{\mathrm{AM}}$ (Pires, Finardi-Filho, 2005), mainly under low temperature assay. The optimum $\mathrm{pH}$ of AM activity from maca extracts, 6.1, was close to optimum pH 6.0 for enzymatic activity from cassava, ichoimo and Peruvian carrot (Table VI). The optimum temperature of AM activity was around $34{ }^{\circ} \mathrm{C}$. This temperature is lower than that in the other sources, which can be explained by the low environmental temperature at cultivation fields and its frost tolerance, as described before.

The most works cited do not include studies on the optimization of $\mathrm{pH}$ and temperature conditions of $\mathrm{PE}$ activity. When the optimization procedure was included, the optimum temperature was found to be higher as in 
TABLE V - ANOVA of PE activity as a function of $\mathrm{pH}\left(\mathrm{x}_{1}\right)$ and temperature $\left(\mathrm{x}_{2}\right)$ of enzyme activity of maca extract

\begin{tabular}{lccccc}
\hline Effects & Sum of squares & Degrees of freedom & Medium squares & F-value & p-value \\
\hline $\mathrm{x}_{1}$ & 40.923 & 1 & 40.923 & 3.78595 & 0.087565 \\
$\mathrm{x}_{1} \mathrm{x}_{1}$ & 812.423 & 1 & 812.423 & 75.16135 & 0.000024 \\
$\mathrm{x}_{2}$ & 8.876 & 1 & 8.876 & 0.82113 & 0.391325 \\
$\mathrm{x}_{2} \mathrm{x}_{2}$ & 140.432 & 1 & 140.432 & 12.99211 & 0.006937 \\
$\mathrm{x}_{1} \mathrm{x}_{2}$ & 0.044 & 1 & 0.044 & 0.00408 & 0.950638 \\
Error & 86.472 & 8 & 10.8091 & - & - \\
Total SS & 1042.649 & 13 & - & - & - \\
\hline
\end{tabular}

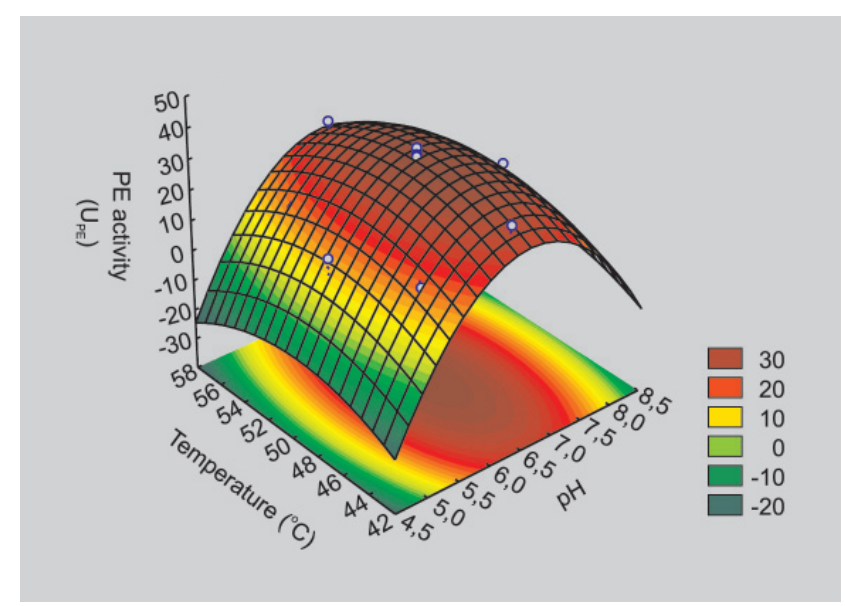

FIGURE 3 - RSM for PE activity $\left(\mathrm{U}_{\mathrm{PE}}\right)$ as a function of $\mathrm{pH}$ and temperature of reaction medium. Experimental conditions at the central point $(0.0)$ were $\mathrm{pH}=6.5$ and temperature $=50{ }^{\circ} \mathrm{C}$. See Tables I and II for details.

acerola, banana, carrot and orange, which was 90, 64, 48.5 and $60{ }^{\circ} \mathrm{C}$, respectively (Table VII). However, only Ly Nguyen and co-workers (2002a; 2002b) used RSM to achieve the optimum conditions for banana and carrot. At the same set of vegetables, the $\mathrm{pH}$ of $\mathrm{PE}$ activity ranged from 6.5 to 9.0 (Table VII).

In contrast to AM activity, extensively studied in roots and tubers, pectinolytic enzymes have been described in fruits and vegetables, especially due to their capacity of softening. Most tubers and roots do not present significant loss of texture during the senescence. However, some of them - like maca and Peruvian carrot - present softening during storage, which could be attributed to endogenous or exogenous source of enzymes. Tables VII and VIII show the values of $\mathrm{pH}$ and temperature assay for PE and PG activity, respectively, from different fruits and vegetables, found in the literature.

The PE of maca showed optimum activity at $\mathrm{pH} 6.6$ and $49.4{ }^{\circ} \mathrm{C}$ according the response surface model. The optimum temperature of $\mathrm{PE}$ activity from fruits, roots and other sources ranged from 25 to $90{ }^{\circ} \mathrm{C}$ (Table VII). However, most works do not include studies on the optimization of $\mathrm{pH}$ and temperature conditions of $\mathrm{PE}$ activity. When the optimization procedures were included, the optimum temperatures were found to be higher as in acerola, banana, carrot and orange, which were 90, 64, 48.5 and $60{ }^{\circ} \mathrm{C}$, respectively (Table VII). At the same set of vegetables, the $\mathrm{pH}$ of $\mathrm{PE}$ activity ranged from 6.5 to 9.0 (Table VII). Although, most of them presented the activity ranging around $\mathrm{pH} 7.0$ to 7.5 , the optimum $\mathrm{pH}$ value for $\mathrm{PE}$ activity from maca was similar to other sources, like apple, pear and Peruvian carrot, which were 6.5.

The maximum $\mathrm{PG}$ activity from maca occurred at $\mathrm{pH}$ 5.4 and $46{ }^{\circ} \mathrm{C}$ according to the response surface model. The PG activity from maca showed higher assay temperature compared to fruits and vegetable (Table VIII). There was no study with RSM or single assay to optimize PG activity to support the values of $\mathrm{pH}$ and temperature mentioned (Table VIII), so the results are not absolute by the lack of better data.

TABLE VI - Assay conditions of $\mathrm{pH}$ and temperature $\left(\mathrm{T},{ }^{\circ} \mathrm{C}\right)$ of AM activity from different sources found in the literature

\begin{tabular}{lcc}
\hline Material & $\mathbf{p H}$ & T $\left({ }^{\circ} \mathbf{C}\right)$ \\
\hline Cassava (Matos da Veiga, 2002) & 6.0 & 60 \\
Ichoimo (Arai, Kawabata, Taniguchi, 1991) & 6.0 & 55 \\
Peruvian carrot (Pires et al., 2002) & 6.0 & 50 \\
Sweet potato (Hagenimana et al., 1994) & $5.8-6.4$ and $5.3-5.8^{\mathrm{a}}$ & 71.5 and $53^{\mathrm{b}}$ \\
Yam (Takase, Ogata, Ito, 1990) & 5.0 & 60 \\
\hline
\end{tabular}

${ }^{\mathrm{a}}$ Optimum $\mathrm{pH}$ of range $\alpha$ - and $\beta$-amylases, respectively. ${ }^{\mathrm{b}}$ Optimum temperature for $\alpha$ - and $\beta$-amylases, respectively 
TABLE VII - Assay conditions of $\mathrm{pH}$ and temperature $\left(\mathrm{T},{ }^{\circ} \mathrm{C}\right)$ of $\mathrm{PE}$ activity from different sources found in the literature

\begin{tabular}{lcc}
\hline Material & $\mathbf{p H}$ & T $\left({ }^{\circ} \mathbf{C}\right)$ \\
\hline Acerola (Assis et al., 2002) & 9.0 & 90 \\
Apple (Castaldo et al., 1989) & 6.5 & 25 \\
Banana (Ly-Nguyen et al., 2002a) & 7.0 & 64 \\
Carrot (Tijskens et al., 1997) & $\mathrm{c}$ & 25 \\
Carrot (Ly-Nguyen et al., 2002b) & 7.4 & 48.5 \\
Grapefruit (Seymour et al., 1991) & 7.0 & 25 \\
Green beans (Laats et al., 1997) & 7.5 & 25 \\
Kiwifruit (Wegrzy, Macrae, 1992) & 7.5 & $\mathrm{~b}$ \\
Mango (Abu-Sarra, Abu-Goukh, 1992; Labib et al., 1995) & 7.0 & 30 \\
Orange (Korner, Zimmermann, Berk, 1980; Versteeg et al., 1980) & 7.5 & 60 \\
Papaya (Fayyaz et al., 1993) & 7.0 & 30 \\
Peach (Javeri, Wicker, 1991) & 8.0 & 60 \\
Pear (Nagel, Patterson, 1967) & $6.5-7.4^{\mathrm{a}}$ & 30 \\
Peruvian carrot (Pires et al., 2005) & 6.5 & 25 \\
Potato (Puri, Solomons, Kramer, 1982) & 7.5 & 55 \\
Potato (Tijskens et al., 1997) & $\mathrm{c}$ & 25 \\
Sapote mamey (Arenas-Ocampo et al., 2003) & 7.5 & 25 \\
\hline
\end{tabular}

${ }^{\text {a }} \mathrm{PE}$ activity was measured in an automatic titrimeter that maintained the $\mathrm{pH}$ at a constant value within the range of 6.5 to 7.4. ${ }^{\mathrm{b}}$ The temperature of $\mathrm{PE}$ activity was not cited in the paper. ${ }^{\mathrm{c}}$ The $\mathrm{pH}$ of $\mathrm{PE}$ activity was not cited in the paper.

TABLE VIII - Assay conditions of $\mathrm{pH}$ and temperature $\left(\mathrm{T},{ }^{\circ} \mathrm{C}\right)$ of $\mathrm{PG}$ activity from different sources found in the literature

\begin{tabular}{lcc}
\hline Material & $\mathbf{p H}$ & $\mathbf{T}\left({ }^{\mathbf{0}} \mathbf{C}\right)$ \\
\hline Banana (Pathak, Sanwal, 1998) & $3.3-4.3^{\mathrm{a}}$ & 37 \\
Mango (Abu-Sarra et al., 1992) & 4.5 & 37 \\
Pear (Nagel et al., 1967) & 4.7 & 30 \\
Peruvian carrot (Pires et al., 2005) & 4.4 & 30 \\
Sapote mamey (Arenas-Ocampo et al., 2003) & 4.0 & $\mathrm{~b}$ \\
Strawberry (Nogata, Ohta, Voragen, 1993) & 5.5 & 37 \\
Tomato (Pressey, 1986; Jackman, Gibson, Stanley, 1995; Yoshida et al., 1984) & 4.5 & 37 \\
\hline
\end{tabular}

${ }^{a}$ Optimum $\mathrm{pH}$ was found to be 3.3, 3.7 and 4.3 for three multiple forms of PG from banana. ${ }^{\mathrm{b}}$ The temperature of PG activity was not cited in the paper.

The RSM is a statistical-mathematical method, which uses quantitative data in an experimental design to determine, and, simultaneously, solve multivariable equations in order to optimize experiments, processes and products. However, it is important to quote that, in the present study, the model reproduces optimal conditions of enzyme activity under the circumstances assayed. Although the RSM presents few experiments in comparison to the conventional method of enzyme characterization, many previous assays are always necessary when the enzyme source is unknown in order to achieve the optimization process.

As mentioned before, few data are available about enzyme activity on the roots of maca to understand its deteriorative process. Nevertheless, the results in this work on the definition of optimal conditions of $\mathrm{pH}$ and temperature of AM, PE and PG enzyme activity can represent an important step concerning the knowledge of the roots deterioration, once the enzymes can be related to the postharvest senescence process of the flavored roots of maca.

\section{RESUMO}

\section{Ensaios preliminares de detecção de atividades amilolítica e pectinolítica em maca (Lepidium meyenii Walp.)}

O objetivo do presente estudo foi determinar valores ideais de $\mathrm{pH}$ e temperatura para avaliar as atividades amilolítica $(\mathrm{AM})$, pectinesterásica $(\mathrm{PE})$ e poligalacturonásica $(\mathrm{PG}) \mathrm{em}$ 
raízes de maca (Lepidium meyenii Walp.). Foi utilizado o modelo de superfície de resposta para atingir valores confiáveis de atividades enzimáticas em extratos brutos. Os valores máximos de atividade AM ocorreram em $\mathrm{pH}$ 6,1 a $33,6{ }^{\circ} \mathrm{C}$, muito próximos do ponto central dos experimentos. Para as atividades de PE e PG, o valores ótimos foram atingidos em pHs 6,6 e 5,4, a 49,4 e $46^{\circ} \mathrm{C}$, respectivamente.

UNITERMOS: Maca. Lepidium meyenii. Amilase. Pectinesterase. Poligalacturonase. Metodologia de superficie de resposta.

\section{ACKNOWLEDGEMENTS}

We thank CNPq and CAPES for the financial support and fellowships.

\section{REFERENCES}

ABU-SARRA, A.F.; ABU-GOUKH, A.A. Changes in pectinesterase, polygalacturonase and cellulose activity during mango fruit ripening. J. Hortic. Sci., v.67, p.561568, 1992.

ARAI, T.; KAWABATA, A.; TANAGUCHI, H. Purification and some properties of ichoimo $\beta$-amylase. Agric. Biol. Chem., v.55, n.2, p.399-405, 1991.

ARENAS-OCAMPO, M.L.; EVANGELISTA-LOZANO, S.; ARANA-ERRASQUIN, R.; JIMÉNEZ-APARICIO, A.; DÁVILA-ORTÍZ, G. Softening and biochemical changes of sapote mamey fruit (Pouteria sapota) at different development and ripening stages. J. Food Biochem., v.27, p.91-107, 2003.

ASSIS, S.A.; MARTINS, A.B.G.; GUAGLIANONI, D.G.; OLIVEIRA, O.M.M.F. Partial purification and characterization of pectin methylesterase from acerola (Malpighia glabra L.). J. Agric. Food Chem., v.50, p.4103-4107, 2002.

BARROS, N. B.; SCARMINIO, I. S.; BRUNS, R. E. Metodologia de superficie de resposta. Planejamento e otimização de experimentos. Campinas, Unicamp, 1996. p.133-186,

BRADFORD, M.M. A rapid and sensitive method for the quantification of microgram quantities of protein utilizing principle of protein-dye binding. Anal. Biochem., v.72, p.248-254, 1976.
CAMPOS, A.D.; DE CARVALHO, V.D. Post-harvest deterioration of cassava. 1. Modification in the rate of physiological deterioration. Pesq. Agropec. Bras., v.25 n.5, p.773-781, 1990.

CASTALDO, D.; QUAGLIUOLO, L.; SERVILLO, L.; BALESTRIERI, C.; GIOVANE, A. Isolation and characterization of pectin methylesterase from apple fruit. J. Food Sci., v.54 (3), p.653-655, 673, 1989.

CHO, Y.K.; AHN, H.K. Purification and characterization of polyphenol oxidase from potato: I. purification and properties. J. Food Biochem., v.23, p.577-592, 1999.

COMAS, M.; MIQUEL, X.; ARIAS G.; DE LA TORRE, M.C. Estudio bromatologico de la maca o paca (Lepidium meyenii). Alimentaria, v.286, n.35, p.85-90, 1997.

DINI, I.; TENORE, G.C.; DINI,A. Glucosinolates from maca (Lepidium meyenii). Biochem. System. Ecol., v.30, p.1087-1090, 2002.

FAYYAZ, A.; ASBI, B.A.; GHAZALI, H.M.; CHE MAN, Y.B.; JINAP, S. Pectinesterase extraction from papaya. Food Chem., v.47, p.183-185, 1993.

GROSS, K.C. A rapid and sensitive spectrophotometric method for assaying polygalacturonase using 2 cyanoacetamide. HortScience, v.17, n.6, p.933-934, 1982.

HAGENIMANA, V.; VÉZINA, L.P.; SIMARD, R.E. Sweet potato $\alpha$ - and $\beta$-amylases: characterization and kinetic studies with endogenous inhibitors. J. Food Sci., v.59 n.2, p.373-377, 1994.

HIROSE, S. Physiological studies on post-harvest deterioration of cassava roots. Japan Agric. Res. Quat., v.19, n.4, p.241-252, 1986.

HONDA, S.; NISHIMURA, Y.; TAKAHASHI, M.; CHIBA, H.; KAKEHI, K. A manual method for the spectrophotometric determination of reducing carbohydrates with 2-cyanoacetamide. Anal. Biochem., v.119, p.194-199, 1982.

JACKMAN, R.L.; GIBSON, H.J.; STANLEY, D.W. Tomato polygalacturonase extractability. J. Food Biochem., v.19, p.139-152, 1995. 
JAVERI, H.; WICKER, L. Partial purification and characterization of peach pectinesterase. J. Food Biochem., v.15, p.241-252, 1991.

KAHN, V.; GOLDSHMIDT, S.; AMIR, J.; GRANIT, A. Some biochemical properties of soluble and bound potato tuber peroxidase. J. Food Sci., v.46, p.756-764, 1981.

KLAVONS, J.A.; BENNET, R.D. Determination of methanol using alcohol oxidase and its application to methyl ester content of pectins. J. Agric. Food Chem., v.34, p.597-599, 1986.

KÖRNER, B.; ZIMMERMANN, G.; BERK, Z. Orange pectinesterase: purification, properties, and effect on cloud stability. J. Food Sci., v.45, p.1203-1206, 1980.

LAATS, M.M.; GROSDENIS, F.; RECOURT, K.; VORAGEN, A.G.J.; WICHERS, H.J. Partial purification and characterization of pectin methylesterase from green beans (Phaseolus vulgaris L.). J. Agric. Food Chem., v.45, p.572-577, 1997.

LABIB, A.A.S.; EL-ASHWAH, F.A.; OMRAN, H.T.; ASKAR,A. Heat-inactivation of mango pectinesterase and polygalacturonase. Food Chem., v.53, p.137-142, 1995.

LYNGUYEN, B.; LOEY, A.V.; FACHIN, D.; VERLENT, I.; HENDRICKX, I.M. Purification, characterization, thermal and high-pressure inactivation of pectin methylesterase from bananas (cv Cavendish). Biotechnol. Bioeng., v.78, n.6, p.683-691, 2002a.

LY NGUYEN, B.; LOEY, A.V.; FACHIN, D.; VERLENT, I.; HENDRICKX, I.M. Partial purification, characterization, and thermal and high-pressure inactivation of pectin methylesterase from carrots (Daucus carrota L.). J. Agric. Food Chem., v.50, p.5437-5444, 2002 b.

MATOS DA VEIGA, E. Caracterização e purificação parcial de $\alpha$-amilase de mandioca (Manihot esculenta Crantz). São Paulo, 2002. 88p. (Dissertação de mestrado -FCF- USP).

NAGEL, C.W.; PATTERSON, M.E. Pectic enzymes and development of the pear (Pyrus communis). J. Food Sci., v.32, p.294-297, 1967.

NOGATA, Y.; OHTA, H.; VORAGEN, A.G.J. Polygalacturonase in strawberry fruit. Phytochem., v.34. n.3, p.617-620, 1993.
OLUOHA, U.; UGOCHUKWU, E.N. Comparison of structure and kinetic mechanism of phosphorylase forms isolated from water yam (Discorea alata) and white yam (Discorea rotundata) tubers. Phytochem., v.40, n.3, p.677-684, 1995.

PASCUAL, C.S.C.I. Caracterização físico-química e purificação de enzimas amilolíticas de mandioca (Manihot esculenta Crantz) cv. Zolhudinha. São Paulo, 2005, 88p. (Dissertação de mestrado - FCF - USP).

PATHAK, N.; SANWAL, G.G. Multiple forms of polygalacturonase from banana fruits. Phytochem., v.48 n.2, p.249-255, 1998.

PIACENTE, S.; CARBONE, V.; PLAZA, A.; ZAMPELLI, A.; PIZZA, C. Investigation of the tuber constituents of maca (Lepidium meyenii Walp.). J. Agric. Food Chem, v.50, p.5621-5625, 2002.

PIRES, T.C.R.; FINARDI-FILHO, F. Extraction and assay of pectic enzymes from Peruvian carrot (Arracacia xanthorriza Bancroft.). Food Chem., v.89, p.85-92, 2005.

PIRES, T.C.R.; VEIGA, E.M.; FINARDI-FILHO, F. Enzimas amilolíticas de mandioquinha-salsa (Arracacia xanthorrhiza Bancroft.). Cienc. Tecnol. Aliment., v.22, n.3, p.278-284, 2002.

PRESSEY, R. Extraction and assay of tomato polygalacturonases. HortScience, v.21, n.3, p.490-492, 1986.

PURI, A.; SOLOMONS, T.; KRAMER, A. Partial purification and characterization of potato pectinesterase. Food Chem., v.8, p.203-213, 1982.

QUIRÓS, C.F.; CÁRDENAS, R.A. Maca (Lepidium meyenii Walp.). In: HERMANN, M.; HELLER, J. Andean roots and tubers: ahipa, arracacha, maca, yacon. Promoting the conservation and use of underutilized and neglected crops. http://www.cipotato.org/market/ars/ar2002/abstracts/ bherm.htm. Accessed in 8 Oct. 2004.

SANDOVAL, M.; OKUHAMA, N.N.; ANGELES, F.M., MELCHOR, V.V.; CONDEZO, L.A.; LAO, J.; MILLER, M.J.S. Antioxidant activity of the cruciferous vegetable maca (Lepidium meyenii). Food Chem., v.79, p.207-213, 2002. 
SEYMOUR, T.A.; PRESTON, J.F.; WICKER, L.; LINDSAY, J.A.; MARSHALL, M.R. Purification and properties of pectinesterases of marsh white grapefruit pulp. J. Agric. Food Chem, v.39, p.1080-1085, 1991.

STREET,H.V. Glycoside hydrolases - amylases: measurement of starch-iodine complex. In: BERGMEYER, H. Methods of enzyme analysis, 2.ed. New York, Academic Press, 1974. v.2. p.313-342.

TAKASE, H.; OGATA, F.; ITO, A. Purification and characterization of $\alpha$-amylases from tubers of taro Colocasia antiquorum. Agric. Biol. Chem., v.54, n.10, p.2741-2742, 1990.

TELLEZ, M.R.; KHAN, I.A.; KOBAISY, M.; SCHRADER, K.K.; DAYAN, F.E.; OSBRINK, W. Composition of the essential oil of Lepidium meyenii (Walp.). Phytochem., v.61, p.149-155, 2002.

TIJSKENS, L.M.M.; WALDRON, K.W.; NG, A.; INGHAM, L.; DIJK, C.V. The kinetics of pectin methyl esterase in potatoes and carrots during blanching. J. Food Eng., v.34, p.371-385, 1997.
TOLEDO, J.; DEHAL, P.; JARRIN, F.; HU, J.; HERMANN, M.; AL-SHEHBAZ, I.; QUIRÓS, C.F. Genetic variability of Lepidium meyenii and other Andean Lepidium species (Brassicaceae) assessed by molecular markers. Ann. Bot., v.82, p.523-530, 1998.

VERSTEEG, C.; ROMBOUTS, F.M.; SPAANSEN, C.H., PILNIK, W. Thermostability and orange juice cloud destabilizing properties of multiple pectinesterases from orange. J. Food Sci., v.45, p.969-971,998, 1980.

WEGRZY, T.F.; MACRAE, E.A. Pectinesterase, polygalacturonase and $\beta$-galactosidase during softening of ethylene-treated kiwifruit. HortScience, v.27, n.8, p.900902, 1992.

YOSHIDA, O.; NAKAGAWA, H.; OGURA, N.; SATO, T. Effect of heat treatment on the development of polygalacturonase activity in tomato fruit during ripening. Plant Cell Physiol., v.25, n.3, p.505-509, 1984.

Recebido para publicação em 26 de abril de 2005. Aceito para publicação em 22 de agosto de 2005. 